\title{
The Amniotic Fluid Transcriptome as a Guide to Understanding Fetal Disease
}

\author{
Lillian M. Zwemer and Diana W. Bianchi \\ Mother Infant Research Institute, Tufts Medical Center, Boston, Massachusetts 02111 \\ Correspondence: dbianchi@tuftsmedicalcenter.org
}

\begin{abstract}
Numerous recent studies have shown the power of cell-free fetal RNA, obtained from amniotic fluid supernatant, to report on the development of the living fetus in real time. Examination of these transcripts on a genome-wide basis has led to new insights into the prenatal pathophysiology of multiple genetic, developmental, and environmental diseases. Each studied condition presents a unique, characteristic fetal transcriptome, which points to specific disrupted molecular pathways. These studies have also improved our knowledge of the normal development of the human fetus, revealing gestational age-related dynamic gene expression from a variety of organs. Analysis of the fetal transcriptome in normal and abnormal development has led to novel approaches for in utero prenatal treatment.
\end{abstract}

\begin{abstract}
$A$ natomical barriers that protect the develop-
Aing human fetus also limit our ability to safely and ethically access and observe the human fetus in an ongoing live pregnancy. Historically, knowledge about fetal development, normal or anomalous, was derived from investigation of either aborted fetuses, the placenta after delivery or cultured cells from amniotic fluid obtained for diagnostic purposes. These tissues have been effectively used to obtain powerful information about human development, but are nonetheless imperfect proxies for the living fetus. Terminated fetuses have been subject to trauma, and prolonged cell-culture often results in genetic changes (Sambuy et al. 2005; Li et al. 2007). Other fetal material used for diagnostic purposes includes cell-free DNA in the maternal blood, which has been applied clinically for fetal Rhesus D detection and gender deter-
\end{abstract}

mination since 2001 (Lewis et al. 2012; Clausen 2014; Hyland et al. 2014). More recently, cell-free fetal (cff) DNA in maternal plasma has been used to screen for fetal aneuploidies (Song et al. 2013; Bianchi et al. 2014). Maternal blood contains both fetal and maternal cell-free nucleic acids, but the fetal contribution to plasma cellfree DNA is a minority (Canick et al. 2013; Rava et al. 2014). To examine pure fetal nucleic acids, therefore, fetal sources such as chorionic villi, placenta or amniotic fluid (AF) must be obtained through a diagnostic procedure.

AF refers to both the cellular and noncellular components of amniotic fluid, as well as the liquid itself. It is created from maternal blood plasma in the first trimester, but later comprised primarily of fetal urine, making it a much more concentrated source of fetal material than other maternal biofluids. It is a complex biofluid,

Editors: Diana W. Bianchi and Errol R. Norwitz

Additional Perspectives on Molecular Approaches to Reproductive and Newborn Medicine available

at www.perspectivesinmedicine.org

Copyright (C) 2015 Cold Spring Harbor Laboratory Press; all rights reserved; doi: 10.1101/cshperspect.a023101

Cite this article as Cold Spring Harb Perspect Med 2015;5:a023101 
L.M. Zwemer and D.W. Bianchi

containing both membrane-bound fetal cells (amniocytes) and myriad cell-free components, including placenta-derived microparticles, proteins, cffDNA and cffRNA from the fetus (Fig. 1) (Larrabee et al. 2005). Amniocytes are suspended in the AF, and sometimes undergo programmed cell-death, releasing cell-free transcripts. cffRNA may also contain transcripts from fetal tissues not directly in contact with AF (Hui et al. 2012a). During the first 20 wk of pregnancy, diffusion between the fetus and the $\mathrm{AF}$ is bidirectional via fetal skin, which is not yet keratinized (Visscher and Narendran 2014). This permeable membrane may provide avenues for cffRNA originating in diverse tissues to contribute to the extracellular RNA found in the AF.

Amniotic fluid removed by amniocentesis can be analyzed in the laboratory setting. Centrifugation of the AF separates the amniocytes from the amniotic fluid supernatant (AFS), within which are suspended cff transcripts. The di- verse types of cffRNA found in AFS reflect the cellular processes active at the time the cells of origin underwent apoptosis-a time capsule from a distinct moment in fetal development. This information can be used to monitor the development of the fetus while characterizing the effects of naturally occurring perturbations, whether genetic or environmental.

In our laboratory, we have examined the $\mathrm{AF}$ transcriptome to measure up-to-the-moment cellular processes occurring in the live human fetus. Isolation and amplification of AFS transcripts, in tandem with a DNAse treatment to preclude genomic DNA contamination, results in a diverse mixture of cffRNA that can be interrogated with high-throughput genomics assays, including expression microarrays. The bioinformatic data resulting from these expression studies can be further examined using in silico functional analyses to investigate the origin of the transcripts and the larger biological

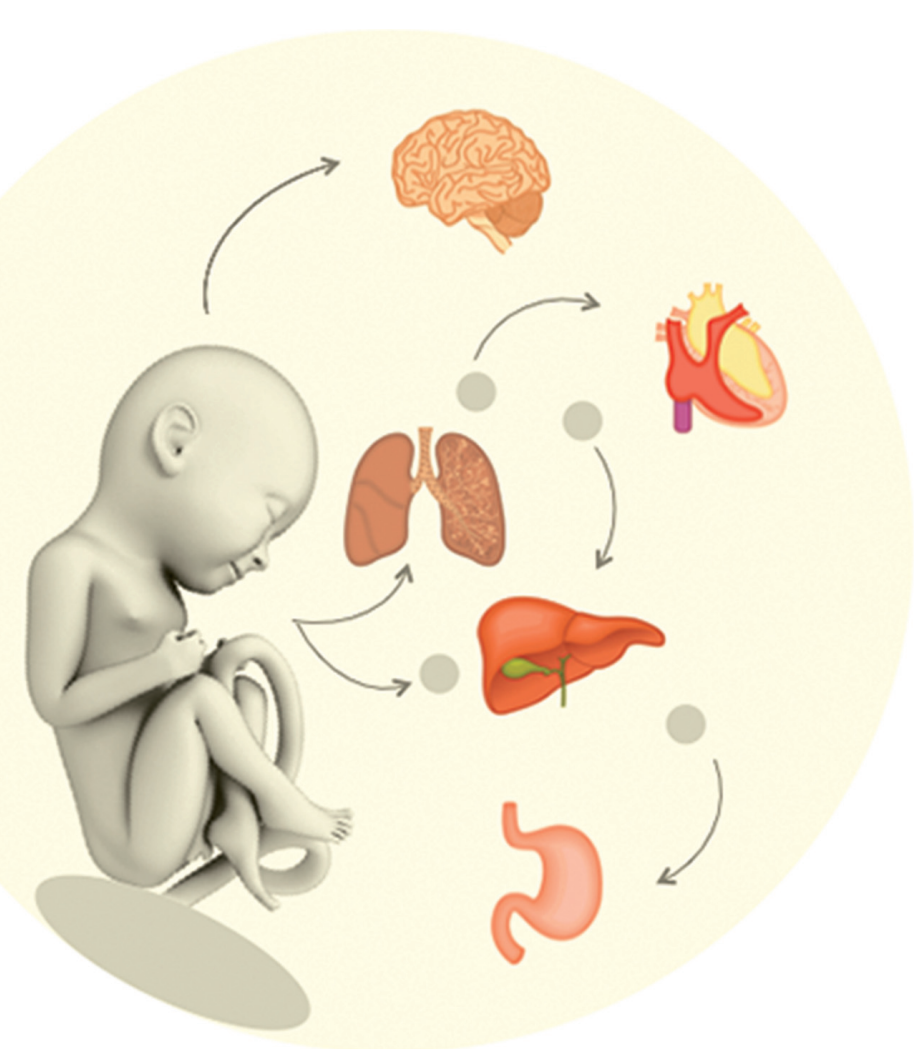

Figure 1. Cell-free fetal RNA is contributed directly by the fetus as well as from apoptotic amniocytes of fetal origin. 
systems and pathways functioning within the developing fetus.

\section{METHODS}

We have capitalized on the abundance of these AFS transcripts to characterize normal fetal development (Hui et al. 2012a, 2013a) while performing discovery-driven research into the developmental underpinnings of several common genetic and nongenetic diseases, each of which will be explored here (Fig. 2, Table 1). Each of these studies made use of cffRNA in residual AF specimens collected for routine clinical indications and used similar methodological approaches (Fig. 3). The RNA was extracted, amplified, labeled and hybridized to either the Affymetrix U133A expression microarray (Larrabee et al. 2005) or the Affymetrix GeneChip Human Genome U133 Plus 2.0 expression microarray (Slonim et al. 2009; Koide et al. 2011; Hui et al. 2012a,b, 2013a,b; Edlow et al. 2014; Massingham et al.2014). Despite the availability of more sophisticated expression microarrays, the U133 Plus 2.0 was chosen because of the need for compatibility with an essential downstream in silico tool, the Connectivity Map (Lamb et al. 2006). For each study, microarray hybridization signal adjustment, normalization, and summary (Bolstad 2004) were followed by either paired or unpaired $t$-tests, with a Benjamini-Hochberg (BH) multiple hypothesis correction (Benjamini and Hochberg 1995) to reveal significantly differentially regulated genes.
Each study identified candidate genes of interest through application of specific thresholds for significance based on corrected p-values, consistency among samples, magnitude of fold-change gene expression, and manual literature searches. Identification of misregulated gene expression pathways and tissue-specific expression was undertaken with a variety of powerful and well established in silico functional genomic analysis tools (Box 1).

\section{STUDIES IN THE DEVELOPING FETUS}

The majority of amniocenteses are performed in the second trimester of pregnancy, between 15 and 21 weeks' gestational age (GA). Common indications for this diagnostic procedure include advanced maternal age and soft markers for aneuploidies, such as elevated levels of alpha-fetoprotein in the maternal serum or an ultrasonographic observation of an enlarged nuchal fold or an echogenic focus in the fetus. In many cases, karyotyping confirms that the fetus is in fact euploid, and a healthy pregnancy follows. cffRNA from these samples can serve as a control for comparison against cffRNA from fetuses with diagnosed diseases.

\section{Preliminary Studies: Disease, Gestational Age and Gender}

The first in vivo whole-transcriptome microarray study of the living human fetus was a proofof-principle experiment designed to consider

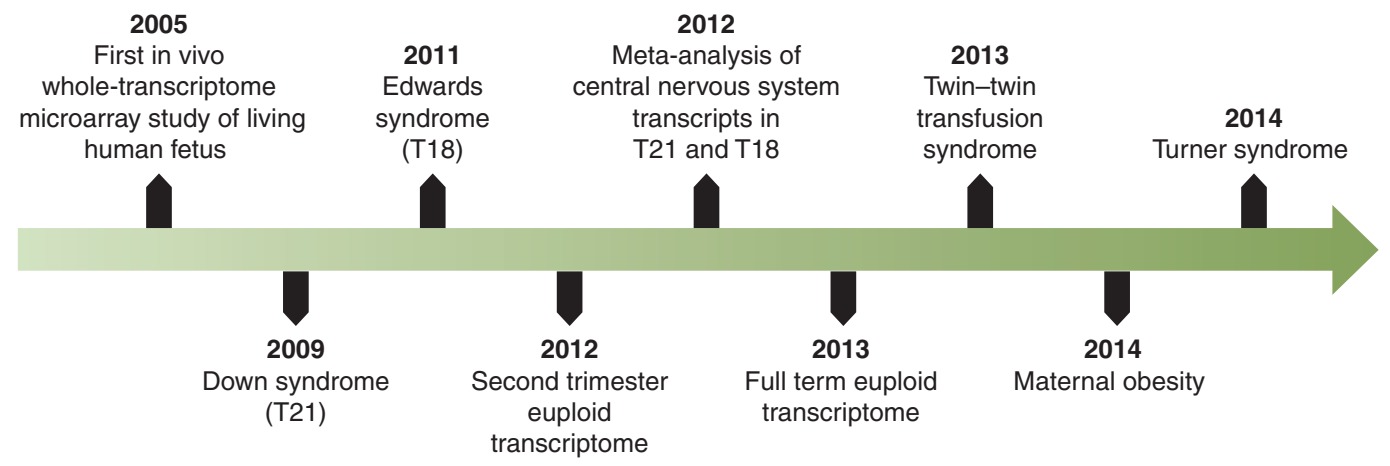

Figure 2. Cell-free fetal RNA in amniotic fluid supernatant provides an opportunity to study fetal gene expression in real-time. 
L.M. Zwemer and D.W. Bianchi

Table 1. Major features of recent studies in fetal biology using amniotic fluid supernatant (AFS) cell-free fetal (cff) RNA

\begin{tabular}{|c|c|c|c|c|c|}
\hline Reference & Biological focus & Samples & Major findings & $\begin{array}{c}\text { Number of } \\
\text { differentially } \\
\text { regulated genes }\end{array}$ & $\begin{array}{c}\text { GEO } \\
\text { accession } \\
\text { number }\end{array}$ \\
\hline $\begin{array}{l}\text { Larrabee et al. } \\
\quad 2005\end{array}$ & $\begin{array}{l}\text { Gestational age, sex, } \\
\text { fetal polyhy- } \\
\text { dramnios }\end{array}$ & 10 & $\begin{array}{l}A Q P 1 \text {, a water transport gene, } \\
\text { was up-regulated in fetuses } \\
\text { with TTTS. Surfactant } \\
\text { proteins, mucins, and } \\
\text { keratins varied with GA. } \\
\text { Placental gene expression was } \\
\text { not observed. }\end{array}$ & $\begin{array}{l}3342-6462 \\
\text { probe sets }\end{array}$ & $\mathrm{N} / \mathrm{A}$ \\
\hline $\begin{array}{l}\text { Slonim et al. } \\
2009\end{array}$ & $\begin{array}{l}\text { Down syndrome } \\
\quad(\mathrm{T} 21)\end{array}$ & 14 & $\begin{array}{l}\text { Misregulation of ion transport } \\
\text { and G protein signaling was } \\
\text { observed, suggesting a link to } \\
\text { the pathological symptoms } \\
\text { in both neural and cardiac } \\
\text { tissues later seen in DS. }\end{array}$ & 414 probe sets & GSE 16176 \\
\hline $\begin{array}{l}\text { Koide et al. } \\
2011\end{array}$ & $\begin{array}{l}\text { Edwards syndrome } \\
\quad \text { (T18) }\end{array}$ & 11 & $\begin{array}{l}\text { Misregulated genes and } \\
\text { pathways of interest included } \\
\text { ROCK1, ion transport, } \\
\text { MHCII/T-cell mediated } \\
\text { immunity, and adrenal } \\
\text { development, among others. } \\
<3 \% \text { of differentially } \\
\text { regulated genes were on } \\
\text { chromosome 18, suggesting } \\
\text { that the majority of } \\
\text { misregulation is caused by } \\
\text { downstream effects. }\end{array}$ & $\begin{array}{l}251 \text { genes ( } 352 \\
\text { probe sets) }\end{array}$ & $\mathrm{N} / \mathrm{A}$ \\
\hline $\begin{array}{l}\text { Hui et al. } \\
\text { 2012a }\end{array}$ & $\begin{array}{l}\text { Euploid fetal } \\
\text { development }\end{array}$ & 12 & $\begin{array}{l}\text { Multiple fetal tissues, including } \\
\text { the central nervous system } \\
\text { tissues, lung, placenta, and } \\
\text { tongue contribute to AFS } \\
\text { cffRNA. }\end{array}$ & $\mathrm{N} / \mathrm{A}$ & GSE 33168 \\
\hline \multirow[t]{2}{*}{$\begin{array}{c}\text { Hui et al. } \\
\text { 2013b }\end{array}$} & \multirow[t]{2}{*}{$\begin{array}{l}\text { Twin-twin } \\
\text { transfusion } \\
\text { syndrome } \\
\text { (TTTS) }\end{array}$} & 16 & $\begin{array}{l}\text { Differential expression of genes } \\
\text { included those with known } \\
\text { functions in fluid } \\
\text { homeostasis, blood pressure } \\
\text { regulation and angiogenesis. } \\
\text { Enrichment was seen in } \\
\text { pathways belonging to } \\
\text { nervous, cardiovascular and } \\
\text { hematological systems. }\end{array}$ & $\begin{array}{l}801 \text { genes ( } 872 \\
\text { probe sets) }\end{array}$ & GSE 47394 \\
\hline & & 10 & $\begin{array}{l}\text { Differentially regulated genes } \\
\text { and pathways include APLN, } \\
\text { and cardiovascular system } \\
\text { development and function } \\
\text { pathways. }\end{array}$ & $\begin{array}{l}611 \text { genes }(780 \\
\text { probe sets) }\end{array}$ & GSE 47394 \\
\hline
\end{tabular}


Table 1. Continued

\begin{tabular}{|c|c|c|c|c|c|}
\hline Reference & Biological focus & Samples & Major findings & $\begin{array}{c}\text { Number of } \\
\text { differentially } \\
\text { regulated genes }\end{array}$ & $\begin{array}{c}\text { GEO } \\
\text { accession } \\
\text { number }\end{array}$ \\
\hline $\begin{array}{c}\text { Edlow et al. } \\
2014\end{array}$ & Maternal obesity & 16 & $\begin{array}{l}\text { Misregulated genes and } \\
\text { pathways include APOD, } \\
\text { FOS, STAT3 and apoptotic } \\
\text { cell-death. Patterns of gene } \\
\text { misregulation suggest that } \\
\text { maternal obesity affects fetal } \\
\text { neurodevelopmental and } \\
\text { metabolic gene regulation. }\end{array}$ & $\begin{array}{c}205 \text { genes (205 } \\
\text { probe sets) }\end{array}$ & GSE 48521 \\
\hline $\begin{array}{r}\text { Massingham } \\
\text { et al. } 2014\end{array}$ & Turner syndrome & 10 & $\begin{array}{l}\text { Misregulated genes point to } \\
\text { involvement of perivascular } \\
\text { tissue, cholesterol } \\
\text { homeostasis, and } \\
\text { hematologic/immune } \\
\text { system. }\end{array}$ & $\begin{array}{c}470 \text { genes ( } 807 \\
\text { probe sets) }\end{array}$ & GSE 58435 \\
\hline
\end{tabular}

questions about the effects of sex, GA, and disease on the transcripts present in AFS (Larrabee et al. 2005). AF was obtained from four pregnancies in which each woman underwent therapeutic amnioreduction for polyhydramnios caused by twin-twin transfusion syndrome
(TTTS) or fetal hydrops. GA ranged from 20 to $32 \mathrm{wk}$ for the three male and one female fetal cases. cffRNA from the pooled AFS of six unaffected euploid male fetuses (average GA = 17 wk) was used as a control. Between 15\% and $29 \%$ of probe sets showed differential ex-

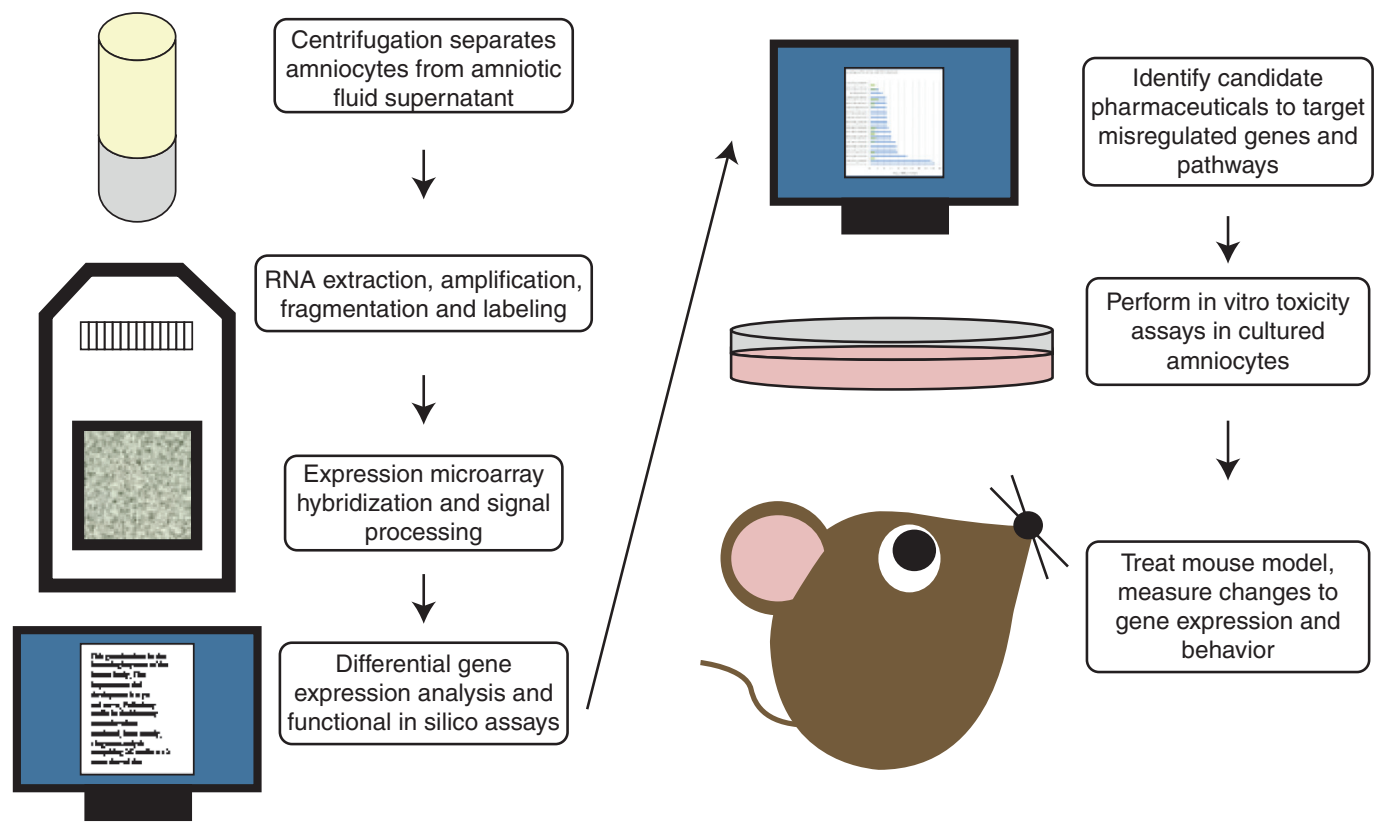

Figure 3. Experimental flow from preparation of cell-free fetal RNA to testing candidate drugs in a mouse model of disease. 
L.M. Zwemer and D.W. Bianchi

\section{BOX 1. RESOURCES FOR IN SILICO FUNCTIONAL ANALYSES}

The Online Mendelian Inheritance in Man Database (OMIM) (see http://www.omim.org) is an online catalog of human genes and genetic disorders. This comprehensive database provides references to relevant molecular and clinical research.

BioGPS (see https://biogps.org, Wu et al. 2009) is a centralized aggregation of protein-coding gene expression data for 78 noncancerous human tissues, including four tissues of fetal origin, and the placenta. Organ specificity was defined by a single organ expression value greater than 30 multiples of the median with the next highest organ expression at no more than one-third the maximum level. A limitation of BioGPS is that it lacks expression profiles for two fetal tissues of relevance to amniotic fluid-kidney and skin.

The Database for Annotation, Visualization and Integrated Discovery (DAVID) (http://david.abcc .ncifcrf.gov, Dennis et al. 2003) synthesizes data from publicly available gene expression atlases into gene enrichment profiles for hundreds of normal and diseased human tissues. Given a list of expressed genes, DAVID can suggest the most likely tissues of origin and identify misregulated pathways.

QIAGEN's Ingenuity Pathway Analysis (IPA) (see http://www.ingenuity.com/products/ipa) is a commercially available platform to identify gene expression pathways enriched within a given data set. IPA will analyze a list of differentially expressed genes to suggest misregulated pathways and cellular functions. IPA has also been used with lists of expressed genes to identify active functions in a given population of fetuses.

Gene Set Enrichment Analysis (GSEA) (see http://www.broadinstitute.org/gsea/index.jsp, Subramanian et al. 2005) can identify sets of genes that are consistently differentially regulated as a group, even when the differential expression of individual genes lacks statistical significance. The Developmental FunctionaL Annotation project at Tufts (DFLAT) (see http://dflat.cs.tufts.edu/data .htm, Wick et al. 2014) is gene ontology annotation specific to the developing human fetus. This database can be used with GSEA to identify developmental processes and functions associated with the observed differential gene expression.

The Connectivity Map (CMap) (see https://www.broadinstitute.org/cmap/, Lamb et al. 2006) is a database of gene expression signatures resulting from the treatment of human cell lines with known FDA-approved drugs. Associated software uses these signatures to suggest drugs that are expected to reverse the user-provided disease-associated gene expression patterns.

The Library of Integrated Network-Based Cellular Signatures (LINCS) (see http://www .lincsproject.org, Duan et al. 2014) shows the observed and predicted gene expression profile effects of treating 20 cell types with 4000 small molecule drugs. LINCS is an extension of CMap that shares the same goal of identifying drugs with a strong therapeutic potential to correct gene expression misregulation.

Developed by the Reproductive Toxicology Center, Reprotox (see http://www.reprotox.org) is a database summarizing the effects of various chemicals, infections and environmental toxins on reproductive health, pregnancy, and fetal development.

pression when compared between the TTTS cases and the pooled male control. Genes of particular relevance to the pathophysiology of hydrops or TTTS were examined, with significantly differential expression of aquaporin 1 (AQP1). These findings served as the basis for a subsequent, more thorough, examination of the effects of TTTS on fetal development (Hui et al. 2013b). Additionally, gene families known to be involved in fetal lung, skin and gastroin- testinal development (surfactant, keratin, and mucin) showed differential expression between the control and cases. This suggested that the population of cffRNA present in AFS is affected by the sex and GA of the fetus. Outside the scope of this review, additional work has since been undertaken, which reveals marked differences between gene expression in the second and third trimesters of euploid fetal life (Hui et al. 2013a). 
Amniotic Fluid Transcriptome and Fetal Disease

Absent from these data was evidence of several genes known to be expressed specifically in the placenta, including corticotropin-releasing hormone $(\mathrm{CRH})$, chorionic somatomammotropin hormone 1 (placental lactogen), and the beta subunit of chorionic gonadotropin $(\beta$ $h C G)$. This led to the conclusion that the placenta did not contribute to AFS cffRNA. More recent experiments, however, suggest that this conclusion may have been incomplete. Subsequent to this early work, changes in the RNA extraction technique to a superior columnbased protocol, the improved chemistry of the amplification system, and an increased number of samples studied, may all contribute to the fact that more recent evidence shows that AFS does show expression of genes that are specific to the placenta (Hui et al. 2012a).

Our laboratory recently conducted a study comparing transcriptomes obtained from the AFS cffRNA and the first-passage amniocytes of eight fetuses (see section Applications to Fetal Therapy, below). In this study, we found that 40 unique placenta-specific genes are present in either the amniocytes or AF of at least seven of the eight individuals (Table 2). These analyses suggest that either the placenta does in fact contribute cffRNA to the AFS and cells to the population of amniocytes, or that these genes are not in fact specific to the placenta, but rather are expressed from other fetal tissues.

\section{The Second Trimester Euploid Fetus}

In 2012, Hui et al. performed a meta-analysis of previously published euploid fetal transcriptomes, considering only those genes expressed by all 12 of the subjects (six male, six female, $\mathrm{GA}=16-21 \mathrm{wk}$ ) (Hui et al. 2012a). This "amniotic fluid core transcriptome” comprised 476 well-annotated genes, including 23 transcripts that were previously known to be expressed in a tissue-specific manner (including those from the liver, lung, and fetal brain). Additionally, functional analysis indicated that the 476 genes reported on six distinct physiologic functions, including musculoskeletal and nervous system development and function. This study detailed the biological richness of amniotic fluid and the
Table 2. Placenta-specific gene expression

\begin{tabular}{|c|c|c|}
\hline Gene symbol & Probe sets & Tissue \\
\hline$A B P 1$ & 1 & AFS \\
\hline ADAM12 & 2 & $\mathrm{AC}$ \\
\hline$A D M$ & 1 & Both \\
\hline AIM1L & 1 & AFS \\
\hline$B M P 1$ & 2 & Both \\
\hline CAPN6 & 2 & AFS \\
\hline CDKN1C & 5 & Both \\
\hline$C O B L L 1$ & 1 & Both \\
\hline CREB3L2 & 1 & Both \\
\hline CRIM1 & 2 & Both \\
\hline$D A B 2$ & 4 & Both \\
\hline DAPK1 & 1 & Both \\
\hline DLG5 & 1 & Both \\
\hline EFHD1 & 1 & Both \\
\hline EGFR & 2 & Both \\
\hline EPS8L1 & 3 & Both \\
\hline EVA1B & 1 & Both \\
\hline EXPH5 & 1 & Both \\
\hline FAM46A & 1 & Both \\
\hline FBN2 & 1 & AFS \\
\hline GDF15 & 1 & $\mathrm{AC}$ \\
\hline GPR126 & 1 & Both \\
\hline$M A F F$ & 1 & Both \\
\hline PAPPA & 2 & $\mathrm{AC}$ \\
\hline PSG3 & 1 & AFS \\
\hline RASA1 & 1 & Both \\
\hline RHOBTB1 & 1 & Both \\
\hline RHOBTB3 & 2 & Both \\
\hline S100P & 1 & AFS \\
\hline SDC1 & 1 & Both \\
\hline SLC5A6 & 1 & Both \\
\hline TAC3 & 1 & AFS \\
\hline TFAP $2 A$ & 1 & AFS \\
\hline TGM2 & 2 & Both \\
\hline TIMP2 & 1 & Both \\
\hline TIMP3 & 2 & AFS \\
\hline TMEM2 & 1 & Both \\
\hline ТРPP3 & 1 & AFS \\
\hline TUSC3 & 1 & Both \\
\hline VGLL1 & 2 & AFS \\
\hline
\end{tabular}

Genes for which probe set(s) known to have placentaspecific expression are observed as present in more than seven of the eight samples of either amniotic fluid supernatant (AFS), amniocytes (AC) or both.

contribution of many organ systems to AFS cffRNA, including those not in direct physical contact with amniotic fluid at the time of amniocentesis. An important implication of this work is the suitability of using cffRNA for the 
study of developmental disorders affecting a variety of fetal tissues, including those involving the central nervous system.

\section{Genetic Disorders: Down Syndrome}

Down syndrome (DS) is estimated to occur in 1:691 live births, making it the most common genetic cause of intellectual disability (Parker et al. 2010). The disease is caused by a partial or complete trisomy of chromosome 21 (Lejeune et al. 1959) and results in a variety of physical differences, including short stature, cardiac defects, intellectual disability, and early-onset dementia. In the United States, prenatal screening for DS is offered for all pregnancies, but in the case of a positive diagnosis, there is no fetal treatment available.

In 2009, work from Slonim et al. began to compare the development of second trimester fetuses with DS (caused by a full trisomy 21, T21) to that of healthy euploid fetuses (Slonim et al. 2009). Expression microarray studies revealed a set of genes significantly differentially regulated between the seven age- and sexmatched pairs of fetuses. Of the 414 probe sets found to be differentially regulated, only five were located on chromosome 21. Using GSEA, a second set of genes, located on chr21q22, was found to be significantly up-regulated as a group, although the individual genes did not show significant signals of dysregulation. Importantly, the level of up-regulation for all 515 genes represented on the array from chromosome 21 was not simply the 1.5 -fold that might be expected because of the presence of a third copy of chromosome 21. Rather, expression differences ranged from fivefold down-regulation to 16-fold up-regulation, suggesting that T21 results in complex intragenomic transcription dysregulation in the fetus. Using DAVID, the list of differentially expressed genes was examined for signatures of disrupted cellular processes. Slonim et al. concluded that the excess of reactive oxygen species in fetal cells disrupts ion transport and signal transduction, leading to pathological symptoms in both neural and cardiac tissues. Oxidative stress had previously been identified in DS (Esposito et al. 2008), but this was the first study to identify the misregulation of intermediate mechanisms, such as G protein signaling and ion transport.

\section{Genetic Disorders: Edwards Syndrome}

Edwards syndrome, or Trisomy 18 (T18), is the second-most common trisomy, occurring in 1:3762 live births (Parker et al. 2010). Because of high levels of prenatal mortality $(75 \%)$ and low rates of postnatal survival $(5 \%-10 \%)$ (Baty et al. 1994; Rasmussen et al. 2003), T18 is poorly studied by comparison with DS. Mortality is most often linked to cardiac and renal malformations or to postnatal feeding difficulties resulting from central nervous system abnormalities. A 2011 study by Koide et al. (2011) sought to compare the genome wide transcriptome of five female fetuses with T18 to six female euploid fetuses. Two hundred and fifty-one (251) genes showed statistically significant differential expression, seven of which were located on chromosome 18, and six of which overlapped with the 419 genes differentially regulated in DS (Table 3, Fig. 4). Specific genes of interest included ROCK1 (Rho-associated kinase 1), known to be involved in valvuloseptal and endocardial formation and ACTH (adrenocorticotropic hormone), which is required for normal morphological and functional development. Many of these genes were different from those first noted as differentially expressed by prior work in first trimester chorionic villi and cultured amniocytes (Altug-Teber et al. 2007). Pathways analysis using IPA and DAVID implicated dysregulation of ion transport functioning, MHCII/T-Cell mediated immunity, adrenal development, and cardiovascular and respiratory system functions. These findings are reminiscent of many clinical observations in T18, including the adrenal cortical zone gross and microscopic hypoplasia.

\section{Genetic Disorders: Neurological Transcripts in DS and T18}

Although trisomies 18 and 21 are the most common live-born autosomal aneuploidies, little was known about the dysregulated biological 
Amniotic Fluid Transcriptome and Fetal Disease

Table 3. Relatively few genes are found to be differentially regulated in more than one study

\begin{tabular}{|c|c|c|c|}
\hline Study & Probe set & $\begin{array}{c}\text { Gene } \\
\text { symbol }\end{array}$ & Gene name \\
\hline \multirow[t]{6}{*}{ DS \& T18 } & 1565537_at & NKX1-1 & NK1 homeobox 1 \\
\hline & 213250_at & CCDC85B & Coiled-coil domain containing 85B \\
\hline & 214420_s_at & CYP2C9 & Cytochrome P450, family 2, subfamily C, polypeptide 9 \\
\hline & 216251_s_at & TTLL12 & Tubulin tyrosine ligase-like family, member 12 \\
\hline & 223296_at & SLC25A33 & $\begin{array}{l}\text { Solute carrier family } 25 \text { (pyrimidine nucleotide carrier), } \\
\text { member } 33\end{array}$ \\
\hline & 230239_at & ROCK1 & Rho-associated, coiled-coil containing protein kinase 1 \\
\hline \multirow[t]{5}{*}{ TTTS \& T18 } & 210835_s_at & CTBP2 & Carboxy-terminal binding protein 2 \\
\hline & 212745_s_at & BBS4 & Bardet-Biedl syndrome 4 \\
\hline & 213417_at & $T B X 2$ & T-box 2 \\
\hline & 221306_at & GPR27 & G protein-coupled receptor 27 \\
\hline & 223007_s_at & TMEM245 & Transmembrane protein 245 \\
\hline \multirow[t]{7}{*}{ TTTS \& Ob } & 202630_at & $A P P B P 2$ & $\begin{array}{l}\text { Amyloid beta precursor protein (cytoplasmic tail) binding } \\
\text { protein } 2\end{array}$ \\
\hline & 205628_at & PRIM2 & Primase, DNA, polypeptide $2(58 \mathrm{kDa})$ \\
\hline & 210457_x_at & HMGA1 & High mobility group AT-hook 1 \\
\hline & 213615_at & LPCAT3 & Lysophosphatidylcholine acyltransferase 3 \\
\hline & 214429_at & MTMR6 & Myotubularin related protein 6 \\
\hline & 219503_s_at & TMEM40 & Transmembrane protein 40 \\
\hline & 219654_at & PTPLA & $\begin{array}{l}\text { Protein tyrosine phosphatase-like (proline instead of catalytic } \\
\text { arginine), member A }\end{array}$ \\
\hline \multirow[t]{6}{*}{ TTTS \& DS } & 206286_s_at & TDGF1 & Teratocarcinoma-derived growth factor 1 \\
\hline & 208255_s_at & FKBP8 & FK506 binding protein $8,38 \mathrm{kDa}$ \\
\hline & 213753_x_at & EIF5A & Eukaryotic translation initiation factor $5 \mathrm{~A}$ \\
\hline & 221766_s_at & FAM46A & Family with sequence similarity 46 , member A \\
\hline & 222389_s_at & WAC & WW domain containing adaptor with coiled-coil \\
\hline & 223122_s_at & SFRP2 & Secreted frizzled-related protein 2 \\
\hline \multirow[t]{7}{*}{ TTTS \& Turner } & 1554239_s_at & ZADH2 & Zinc binding alcohol dehydrogenase domain containing 2 \\
\hline & 202124_s_at & TRAK2 & Trafficking protein, kinesin binding 2 \\
\hline & 204191_at & IFNAR1 & Interferon (alpha, beta and omega) receptor 1 \\
\hline & 208767_s_at & LAPTM $4 B$ & Lysosomal protein transmembrane 4 beta \\
\hline & 211678_s_at & RNF114 & Ring finger protein 114 \\
\hline & 212415_at & SEPT6 & Septin 6 \\
\hline & 212530_at & NEK7 & NIMA-related kinase 7 \\
\hline \multirow[t]{2}{*}{ Turner \& T18 } & 226235_at & LINC00667 & Long intergenic nonprotein coding RNA 667 \\
\hline & 236219_at & SLC35G1 & Solute carrier family 35 , member G1 \\
\hline Turner \& DS & 223792_at & ZNF2 & Zinc finger protein 2 \\
\hline \multirow[t]{5}{*}{ Turner \& Ob } & 201111_at & CSE1L & CSE1 chromosome segregation 1-like (yeast) \\
\hline & 207723_s_at & KLRC3 & Killer cell lectin-like receptor subfamily C, member 3 \\
\hline & 209176_at & SEC23IP & SEC23 interacting protein \\
\hline & 211741_x_at & PSG3 & Pregnancy-specific beta-1-glycoprotein 3 \\
\hline & 223054_at & DNAJB11 & DnaJ (Hsp40) homolog, subfamily B, member 11 \\
\hline
\end{tabular}

DS, Down syndrome (Slonim et al. 2009); Ob, obesity (Edlow et al. 2014); T18, Edwards syndrome (Koide et al. 2011); TTTS, Twin-twin transfusion syndrome (Hui et al. 2013b); Turner, Turner syndrome (Massingham et al. 2014). 
L.M. Zwemer and D.W. Bianchi

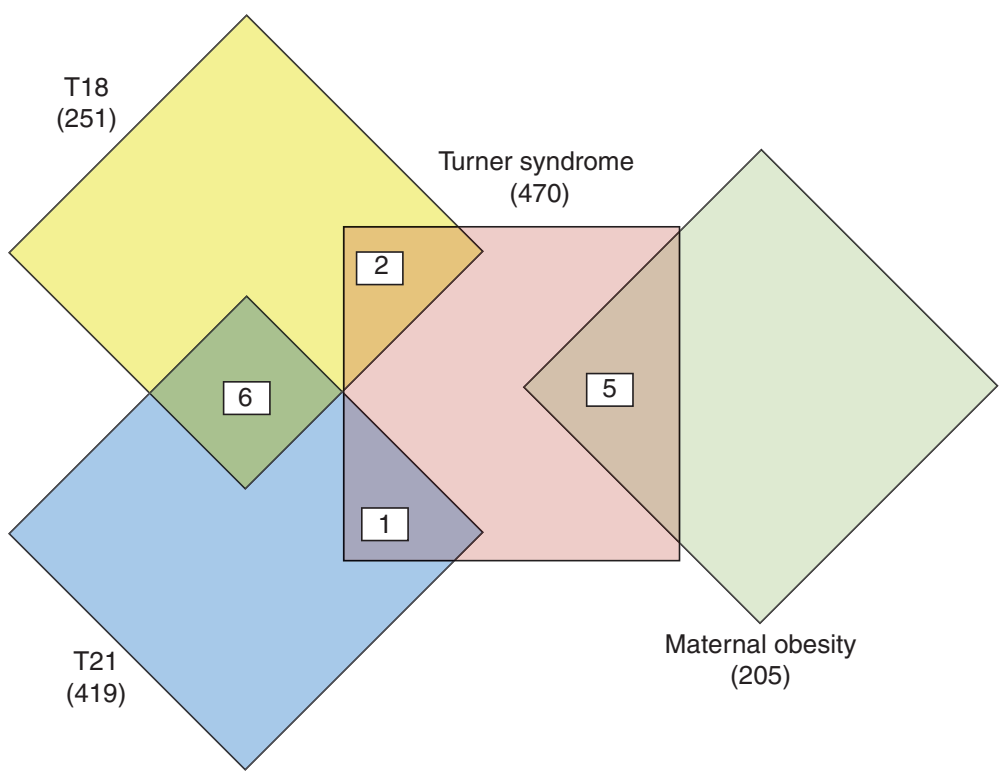

Figure 4. Examined transcriptomes share few misregulated genes. Numbers in parentheses show total numbers of misregulated genes for a given study (vs. GA- and sex-matched controls). Numbers in white squares represent common genes that are dysregulated in both overlapping conditions.

pathways that resulted in well-characterized fetal morphological anomalies. In the studies of both DS and T18, differentially regulated genes included those that are thought to be expressed specifically from the central nervous system. This finding motivated a 2012 meta-analysis to mine previously published data (Slonim et al. 2009; Koide et al. 2011; Hui et al. 2012a) with a specific focus on neural transcripts (Hui et al. 2012b). Hui et al. identified the 536 genes universally present in the cffRNA of 12 of 12 euploid samples, 746 genes universally present in the cffRNA of five of five fetuses with T18, and the 1184 genes universally present in the cffRNA of seven of seven fetuses with DS. Using the functional analytics available through DAVID, IPA, and BioGPS, Hui et al. identified enrichment of the nervous system among differentially regulated genes in the aneuploid fetuses. This meta-analysis also reexamined genes previously identified as being differentially expressed in aneuploid fetuses and discovered that several are known to be expressed specifically from the central nervous system, including ones known to be critical for nervous system development. These genes included NEUROD2 (neuronal differentiation 2, downregulated in T18), which induces neurogenic differentiation and SOX11 (SRY-related HMGbox Gene 11, down-regulated in DS), a transcription factor that is essential for pan-neuronal protein expression and axonal growth of sensory neurons.

\section{Genetic Disorders: Turner Syndrome}

Turner syndrome (TS) is a sex chromosome aneuploidy (45, X female) characterized by anatomical differences, including short stature, a webbed neck, dysfunction of the kidneys, heart and ovaries, and an increased risk of autoimmune disorders. Comorbidities include obesity and glucose intolerance, scoliosis, atherosclerosis, hyperlipidemia, and juvenile rheumatoid arthritis. In a 2014 study, Massingham et al. (2014) compared five second trimester female fetuses, monosomic for the $\mathrm{X}$ chromosome, to five GAand sex-matched euploid control fetuses. Four hundred and seventy (470) differentially regulated genes were identified (BHp <0.015). 
Genes showing the most extreme differential expression (fold-change $\geq 5$ ) were submitted to IPA, and tissue-specific genes belonging to the top five most common organ systems were subjected to manual curation using Online Mendelian Inheritance in Man (OMIM). These in silico analyses revealed that among differentially regulated genes, there was enrichment for genes and pathways related to known symptoms of TS. This includes NFATC3, which is involved in perivascular tissue remodeling (of interest given that coarctation of the aorta is a feature of TS) and LDLR, which is involved in cholesterol homeostasis (of interest given that hyperlipidemia is a feature of TS). This enrichment also encompassed genes related to the hematologic/immune pathway, which may relate to the autoimmune disorders commonly seen in women with TS (Table 1). Additionally, by identifying sets of differentially regulated genes, this study revealed several candidate genes not previously known to be associated with the condition, which are suitable for follow-up study. A "Turner syndrome transcriptome" was also created, comprised of genes for which each of the five TS samples consistently yielded a "present" signal on the microarray. The TS transcriptome was compared against other fetal transcriptomes (e.g., euploid [Hui et al. 2012a], trisomies 18 and 21 [Hui et al. 2012b]) and was subjected to BioGPS analysis to identify tissue-specific transcripts enriched specifically in amniotic fluid from fetuses with TS.

The four studies presented above all examined the genome-wide changes to fetal gene expression that result from a single chromosome aneuploidy. As a whole, they suggest that the pathophysiology of these disorders does not arise from simple gene dosage effects of the aneuploid chromosome. Rather, an intragenomic web of expression misregulation contributes to create a distinct molecular and clinical phenotype that is characteristic of each disease, and shares few similarities with the others (Table 3 , Fig. 4). Studies of nongenetic complications of pregnancy, such maternal obesity and further work on TTTS, have also yielded compelling evidence of disease-specific fetal molecular phenotypes, and are examined below.

\section{Developmental Disorders: Twin-Twin Transfusion Syndrome}

TTTS is a complication of monochorionic diamniotic twin pregnancy associated with very high perinatal mortality rates (Shah and Chaffin 1989; Gonsoulin et al. 1990; Saunders et al. 1992). Shared placental vascular anastomoses allow a net transfer of blood from one twin (the donor) to the other (the recipient). This disrupts regulation of fluid balance and fetal growth, leading to cardiovascular dysfunction and major neurodevelopmental irregularities in the fetus, as well as low birth-weight and premature delivery. TTTS diagnoses are further divided into stages; fetuses with stages II and III TTTS were the focus in this study. Stages II and III both show discordant AF volumes relative to a healthy fetus, but a stage III diagnosis involves a critically abnormal Doppler study for either the donor twin, the recipient twin, or both.

The typical treatment for TTTS is amnioreduction of the recipient twin combined with prenatal laser ablation of the shared placental anastomoses, which results in significantly improved survival of one or both fetuses (Senat et al. 2004; Roberts et al. 2008). Long-term health complications persist, however, including abnormal neurological function and increased risk of cardiac structural dysmorphology and long-term diastolic dysfunction. A long-standing question within the field has been whether these morbidities arise from the disease itself, or are complications resulting from the laser ablation treatment. As discussed above, preliminary examination of fetal gene expression in the context of TTTS suggested differential expression of the water-transport gene $A Q P 1$ in the recipient twin (Larrabee et al. 2005). In 2013, Hui et al. revisited this disease, making a focused study of transcriptome-wide changes to fetal gene expression of the recipient twin in the second trimester, comparing gene expression between unaffected fetuses and fetuses with stage III TTTS, and comparing expression for fetuses with stages II and III TTTS.

In this study, eight recipient twins were each paired (for sex and GA) with eight healthy sin- 
gleton controls. Eight hundred and one (801) genes showed statistically significant differential gene expression between TTTS and unaffected fetuses. This list included genes with known functions in fluid homeostasis, blood pressure regulation and angiogenesis. Additionally, functional analyses of the 801 genes identified their enrichment in physiological systems consistent with known long-term complications of TTTS in the cardiovascular and nervous systems (Hui et al. 2013b).

Real-time quantitative PCR validation was performed for six of these genes, selected for clinical significance and magnitude of gene expression fold-change. The microarray results were confirmed for four of the six, including NRXN3, NTRK3, FLT1, and AVPR1A, which are involved in synapse formation, nerve growth and formation of cardiac structures, angiogenesis and vasoconstriction, respectively. The amniotic fluid used in these studies was collected just before the initiation of laser ablation treatment. This allowed the investigators to conclude that the neurological and cardiovascular anomalies suggested by the differential gene expression analysis are intrinsic to TTTS itself, and are not a side effect of the laser ablation treatment.

In a second experiment from this same study, five stage II and five stage III samples were compared as groups in an unpaired analysis. Six hundred and eleven (611) genes showed statistically significant differential expression between these two groups. Functional analysis using IPA showed enrichment of genes associated with cardiovascular system development and function.

\section{Environmental Exposures: Maternal Obesity}

Maternal obesity is present in about one third of pregnancies in the United States (Flegal et al. 2012). Maternal obesity during pregnancy has been associated with neurodevelopmental and metabolic conditions in the offspring, but the developmental underpinnings are poorly studied. In 2014, Edlow et al. conducted a study to examine whole-transcriptome differences in fetal gene expression from pregnancies of eight obese (BMI $\geq 30)$ and eight lean women (BMI $<25)$. Two hundred and five (205) genes were found to be significantly differentially regulated between each of the eight pairs of fetuses, which were matched for sex and GA. At ninefold upregulation, apolipoprotein $\mathrm{D}(A P O D)$ was the most up-regulated gene in fetuses of obese women. $A P O D$ is highly expressed in tissues of the central nervous system and is essential to proper lipid regulation. Functional analysis of the differentially regulated genes using IPA suggested down-regulation of apoptotic cell death, particularly in nervous system pathways involving the cerebral cortex. IPA analysis also allowed the prediction of activation of transcript regulators in fetuses of obese women, identifying three genes involved in estrogen and cytokine signaling, ESR1/2, FOS, and STAT3. Together, these findings suggest that maternal obesity creates a proestrogenic and proinflammatory intrauterine environment.

\section{APPLICATIONS TO FETAL THERAPY}

The initial goal of these studies was to assess fetal development in several organ systems at a discrete time point of fetal life in response to a known abnormality (genetic, hemodynamic, or environmental). The detail and complexity revealed by these investigations has allowed for progression toward a second goal- the development of in utero treatments that can be offered at the time of disease diagnosis. Treatment at these critical early stages of development could mitigate the life-long health problems that originate in altered fetal development.

Work in our laboratory is already underway to develop prenatal treatments for oxidative stress in human fetuses with DS (Guedj and Bianchi 2013a; Guedj et al. 2014). Compounds identified using the Connectivity Map database (see http://www.broadinstitute.org/cmap/), including the antioxidant drug apigenin, are being tested through in vitro studies on amniocytes from human AF and in vivo studies in the Ts1Cje mouse models of Down syndrome (Guedj et al. 2013b). A preliminary stage of candidate drug testing is assessing the drug's toxicity and effects on cell proliferation in vitro through treatment 
of cells in culture. Secondarily, the efficacy of the drug in reducing oxidative stress is objectively measured by the COMET assay that quantifies the number of double stranded DNA breaks per cell (Tice et al. 2000). In vivo studies include embryonic brain gene expression analysis, as well as neonatal and adult behavioral testing in apigenin-treated and untreated Ts1Cje mice and their littermate controls (Fig. 3). The in vitro experiments require mitotically active cells, so fresh amniocytes are used in lieu of cffRNA.

\section{Comparing AFS Cell-Free and Cellular RNA}

The cffRNA found in AFS is a complex assortment of transcripts from many organs (Hui et al. 2012a). With this in mind, we assessed the suitability of amniocytes as a proxy for cffRNA, by comparing gene expression in cffRNA and first passage amniocytes. In a previously unpublished study, whole amniotic fluid was collected from eight second-trimester fetuses (six singletons and one twin-pair, five male and three female) free from known structural and cytogenetic anomalies. The median GA was $17 \mathrm{wk}$ (range $16^{5} /{ }_{7}-22^{4} / 7 \mathrm{wk}$ ). For each sample, the
Amniotic Fluid Transcriptome and Fetal Disease

amniocytes were separated from the AFS by centrifugation and the cells were cultured for one passage. Thus, only mitotically active cells remained. Cellular RNA was then extracted from the amniocytes and cffRNA was extracted from the AFS of the same sample. Microarray expression analysis of this RNA resulted in surprising conclusions, including the fact that the cffRNA comprised a subset of the transcripts observed in the amniocytes (Fig. 5). Analysis by BioGPS and DAVID of the genes that were significantly differentially expressed between the two data sets showed that relative to the AFS cffRNA, amniocytes were enriched for transcripts originating from endothelial, fibroblast, and aortic cells. Compared with amniocytes, cffRNA showed enrichment in transcripts originating from the tongue and intestine.

The higher quality of cellular RNA compared with cffRNA likely contributes to the finding that amniocytes contained transcripts for a greater number of genes (10,825 vs. 7531) (Fig. 5). Cellular RNA is better protected from degradation, and so more consistently observed in the samples. Indeed, $52 \%$ of the genes observed in any one amniocyte RNA sample are observed consistently in all eight samples; this number drops to $36 \%$ for AFS cffRNA. Addi-

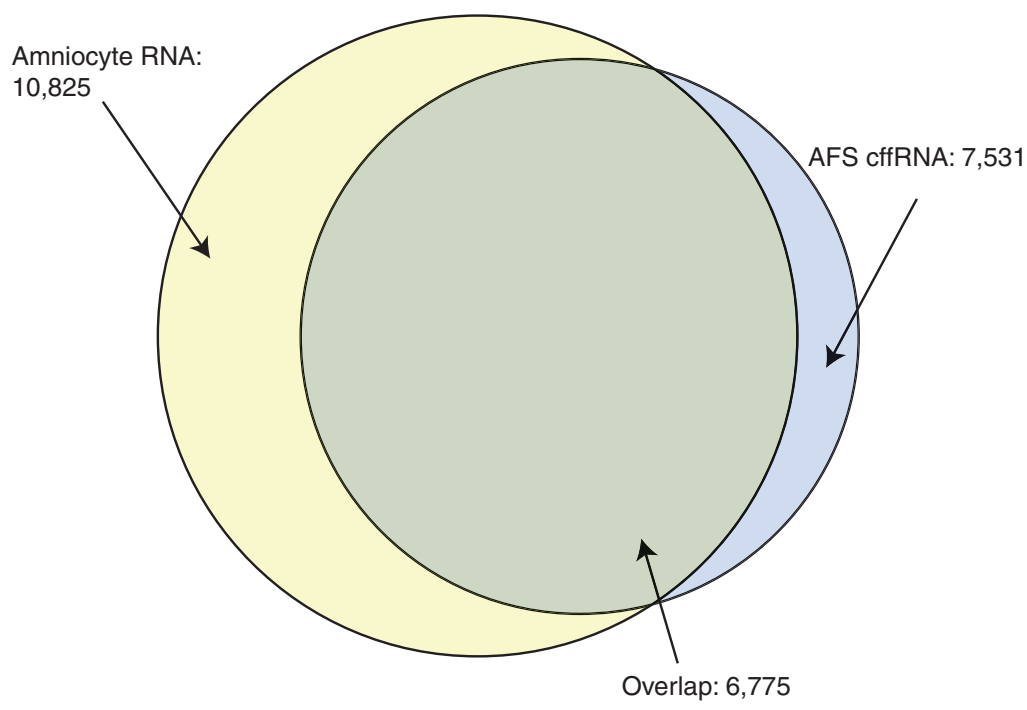

Figure 5. The majority of genes detected as present in amniotic fluid supernatant cell-free fetal RNA (AFS cffRNA) are also detected as present in amniocyte RNA. 
L.M. Zwemer and D.W. Bianchi

tionally, it may be that although a diversity of fetal tissues contribute cells to AF, not all of these tissues or cells go on to contribute to the cffRNA found in AFS, resulting in a decreased number of transcripts in cffRNA relative to those seen in amniocyte cellular RNA.

Considering the presence of some of the genes of interest from the Hui et al. (2012a) "transcriptome" study shows that nearly all the genes that are observed in the AFS cffRNA are also observed in amniocyte RNA, including transcripts specific to the central nervous system (Table 4). There are some differences between the two AFS cffRNA studies, perhaps caused by the degraded nature of cffRNA resulting in inconsistent microarray signal calling, or to variations in the sex and GA of the studied fetuses. However, these data show that amniocytes are

Table 4. Tissue-specific gene expression

\begin{tabular}{|c|c|c|c|c|c|}
\hline Probe Set & $\begin{array}{l}\text { Gene } \\
\text { symbol }\end{array}$ & Gene name & Tissue & $\begin{array}{c}\text { AFS } \\
\text { cffRNA }\end{array}$ & $\mathrm{AC}$ \\
\hline 207608_x_at & CYP1A2 & $\begin{array}{l}\text { Cytochrome P450, family } 1 \text {, subfamily A, } \\
\text { polypeptide } 2\end{array}$ & Adult liver & 8 & 8 \\
\hline 207300_s_at & F7 & $\begin{array}{l}\text { Coagulation factor VII (serum prothrombin } \\
\text { conversion accelerator) }\end{array}$ & Adult liver & 8 & 7 \\
\hline 213940_s_at & $F N B P 1$ & Formin binding protein 1 & B lymphoblasts & 8 & 8 \\
\hline 221923_s_at & NPM1 & $\begin{array}{l}\text { Nucleophosmin (nucleolar phosphoprotein } \\
\text { B23, numatrin) }\end{array}$ & B lymphoblasts & 8 & 8 \\
\hline 214354_x_at & SFTPB & Surfactant protein B & Adult lung & 7 & 6 \\
\hline 215454_x_at & SFTPC & Surfactant protein C & Adult lung & 2 & 1 \\
\hline 33322_i_at & SFN & Stratifin & Bronchial & 8 & 8 \\
\hline 33323_r_at & SFN & & epithelial cells & 8 & 8 \\
\hline 218309_at & CAMK2N1 & $\begin{array}{l}\text { Calcium/calmodulin-dependent protein } \\
\text { kinase II inhibitor } 1\end{array}$ & Prefrontal cortex & 8 & 8 \\
\hline 201853_s_at & $C D C 25 B$ & $\begin{array}{l}\text { Cell division cycle } 25 \text { homolog B } \\
\quad \text { (Schizosaccharomyces pombe) }\end{array}$ & $\mathrm{CD} 4^{+} \mathrm{T}$ cells & 8 & 8 \\
\hline 217878_s_at & CDC27 & $\begin{array}{l}\text { Cell division cycle } 27 \text { homolog (Saccharomyces } \\
\text { cerevisiae) }\end{array}$ & $\begin{array}{l}\text { CD71 }{ }^{+} \text {early } \\
\text { erythroid }\end{array}$ & 8 & 8 \\
\hline 207030_s_at & CSRP2 & Cysteine and glycine-rich protein 2 & Fetal brain & 8 & 8 \\
\hline 204971_at & CSTA & Cystatin A (stefin A) & Tongue & 8 & 1 \\
\hline 209570_s_at & D4S234E & $\begin{array}{l}\text { DNA segment on chromosome } 4 \text { (unique) } 234 \\
\text { expressed sequence }\end{array}$ & Fetal brain & 8 & 7 \\
\hline 201278_at & $D A B 2$ & $\begin{array}{l}\text { Disabled homolog } 2 \text {, mitogen-responsive } \\
\text { phosphoprotein (Drosophila) }\end{array}$ & Placenta & 7 & 8 \\
\hline 201681_s_at & DLG5 & Discs, large homolog 5 (Drosophila) & Placenta & 8 & 8 \\
\hline 214395_x_at & EEF1D & $\begin{array}{l}\text { Eukaryotic translation elongation factor } 1 \text { delta } \\
\quad \text { (guanine nucleotide exchange protein) }\end{array}$ & Fetal thyroid & 8 & 8 \\
\hline 215017_s_at & FNBP1L & Formin binding protein 1-like & Fetal brain & 8 & 8 \\
\hline 218330_s_at & $N A V 2$ & Neuron navigator 2 & Fetal brain & 8 & 8 \\
\hline 201928_at & PKP4 & Plakophilin 4 & Spinal cord & 8 & 8 \\
\hline 216470_x_at & $P R S S 1 / 2 / 3$ & $\begin{array}{l}\text { Potease, serine, } 1 \text { (trypsin 1) / protease, serine, } \\
2(\text { trypsin } 2) / \text { protease, serine, } 3\end{array}$ & Pancreas & 8 & 8 \\
\hline 205064_at & $S P R R 1 B$ & Small proline-rich protein $1 \mathrm{~B}$ & Tongue & 8 & 2 \\
\hline 208539_x_at & $S P R R 2 B$ & Small proline-rich protein $2 \mathrm{~B}$ & Tongue & 8 & 0 \\
\hline 212774_at & ZNF238 & Zinc finger protein 238 & $\begin{array}{l}\text { Cerebellar } \\
\text { peduncles }\end{array}$ & 8 & 8 \\
\hline
\end{tabular}

Genes for which probe set(s) known to have tissue-specific expression and are present in 12 of 12 amniotic fluid supernatant (AFS) cell-free fetal (cff) RNA samples contributing to the amniotic fluid core transcriptome (Hui et al. 2012a). Their presence in $\mathrm{n}$ of 8 AFS cffRNA or amniocyte (AC) RNA samples is indicated. 
reasonably equivalent to AFS, and can be used as a proxy for the fetus when testing the effects of different therapies.

\section{FUTURE DIRECTIONS}

\section{RNA-Sequencing}

With the increasing affordability and availability of RNA-Sequencing (RNA-Seq), many microarray-based laboratory and clinical applications are transitioning to this newer, more efficient platform. Pilot experiments from our laboratory comparing the suitability of RNASeq and expression microarrays for studying AFS cffRNA have shown that the former is currently more susceptible to the technical challenges of working with cffRNA (Zwemer et al. 2014). cffRNA is by nature degraded and dilute, necessitating the development of a custom protocol for library creation. Work on this goal is currently underway in our laboratory, and will eventually allow our knowledge of fetal gene expression to expand to include many more genes than those represented on the HGU133 Plus 2.0 microarray.

The power of a whole-transcriptome approach lies in the ability to generate novel hypotheses for experimental approaches. In addition to creating new knowledge about relatively unknown aspects of fetal disease, these studies result in the identification of genes that are misregulated at the very time in development when essential neurological and physiological patterns are being established. Correcting gene misregulation through the use of pharmacological in utero treatments could minimize or prevent altered physiology. The work that began in DS in 2009 by examining cffRNA has resulted in preliminary experiments treating a mouse model of DS during pregnancy (Fig. 3). The ultimate goal, however, is to translate the work to human pregnancies.

\section{CONCLUDING REMARKS}

Taken together, this set of disease studies has shown the unique power of cffRNA to identify novel aspects of the prenatal development of multiple fetal organs in both healthy and dis-
Amniotic Fluid Transcriptome and Fetal Disease

eased states, allowing identification of candidate disease-related genes. These studies also support the hypothesis that the developmental underpinnings of a variety of genetic and environmental diseases can be observed as early as the second trimester of pregnancy. Furthermore, each of these studies supports the view that altered gene expression in these affected fetuses is a genome-wide phenomenon, extending beyond the causal aneuploidy, to produce a unique and characteristic pattern of fetal gene expression. Finally, several studies have shown that the source of cffRNA can be traced to a variety of fetal organs as well as the placenta, and that fetal transcriptomes between first-passage amniocytes and AFS cffRNA share many similarities, making both useful resources in the efforts to develop prenatal therapies.

\section{ACKNOWLEDGMENTS}

This work was supported by National Institutes of Health (NIH) Grant CD R01 HD42053-10 (D.W.B.) and by the Founder's Fund at Tufts Medical Center.

\section{REFERENCES}

Altug-Teber O, Bonin M, Walter M, Mau-Holzmann UA Dufke A, Stappert H, Tekesin I, Heilbronner H, Nieselt K, Riess O. 2007. Specific transcriptional changes in human fetuses with autosomal trisomies. Cytogenet Genome Res 119: $171-184$

Baty BJ, Blackburn BL, Carey JC. 1994. Natural history of trisomy 18 and trisomy 13: I: Growth, physical assessment, medical histories, survival, and recurrence risk. Am J Med Genet 49: 175-188.

Benjamini Y, Hochberg Y. 1995. Controlling the false discovery rate: A practical and powerful approach to multiple testing. J R Stat Soc Series B Stat Methodol 47: 289300.

Bianchi DW, Parker RL, Wentworth J, Madankumar R, Saffer C, Das AF, Craig JA, Chudova DI, Devers PL, Jones KW, et al. 2014. DNA sequencing versus standard prenatal aneuploidy screening. $N$ Engl J Med 370: 799-808.

Bolstad BM. 2004. "Low level analysis of high-density oligonucleotide array data: Background, normalization and summarization.” PhD thesis, University of California, Berkeley.

Canick JA, Palomaki GE, Kloza EM, Lambert-Messerlian GM, Haddow JE. 2013. The impact of maternal plasma DNA fetal fraction on next generation sequencing tests for common fetal aneuploidies. Prenatal Diagn 33: $667-$ 674. 
L.M. Zwemer and D.W. Bianchi

Clausen FB. 2014. Integration of noninvasive prenatal prediction of fetal blood group into clinical prenatal care. Prenatal Diagn 34: 409-415.

Dennis G Jr, Sherman BT, Hosack DA, Yang J, Gao W, Lane HC, Lempicki RA. 2003. DAVID: Database for Annotation, Visualization, and Integrated Discovery. Genome Biol 4: P3.

Duan Q, Flynn C, Niepel M, Hafner M, Muhlich JL, Fernandez NF, Rouillard AD, Tan CM, Chen EY, Golub TR, et al. 2014. LINCS Canvas Browser: Interactive web app to query, browse and interrogate LINCS L1000 gene expression signatures. Nucleic Acids Res 42: W449-W460.

Edlow AG, Vora NL, Hui L, Wick HC, Cowan JM, Bianchi DW. 2014. Maternal obesity affects fetal neurodevelopmental and metabolic gene expression: A pilot study. PLOS ONE 9: e88661.

Esposito G, Imitola J, Lu J, De Filippis D Scuderi C, Ganesh VS, Folkerth R, Hecht J, Shin S, Iuvone T. 2008. Genomic and functional profiling of human Down syndrome neural progenitors implicates $\mathrm{S100B}$ and aquaporin 4 in cell injury. Hum Mol Genet 17: 440-457.

Flegal KM, Carroll MD, Kit BK, Ogden CL. 2012. Prevalence of obesity and trends in the distribution of body mass index among US adults, 1999-2010. JAMA 307: 491497.

Gonsoulin W, Moise KJ Jr, Kirshon B, Cotton DB, Wheeler JM, Carpenter RJ Jr. 1990. Outcomes of twin-twin transfusion diagnosed before 28 weeks of gestation. Obstet Gynecol 75: 214-216.

Guedj F, Bianchi DW. 2013a. Noninvasive prenatal testing creates and opportunity for antenatal treatment of Down syndrome. Prenat Diagn 33: 614-618.

Guedj F, Hines D, Foley JC, Haydon PG, Bianchi DW. 2013b. Translating the transcriptome to develop antenatal treatments for fetuses with Down syndrome. Reprod Sci 20: 64A.

Guedj F, Bianchi DW, Delabar J-M. 2014. Prenatal treatment of Down syndrome: A reality? Curr Opin Obstet Gynecol 26: $92-103$.

Hui L, Slonim DK, Wick HC, Johnson KL, Bianchi DW 2012a. The amniotic fluid transcriptome: A source of novel information about human fetal development. $\mathrm{Ob}$ stet Gynecol 119: 111-118.

Hui L, Slonim DK, Wick HC, Johnson KL, Koide K, Bianchi DW. 2012b. Novel neurodevelopmental information revealed in amniotic fluid supernatant transcripts from fetuses with trisomies 18 and 21. Hum Genet 131: 17511759.

Hui L, Wick HC, Edlow AG, Cowan JM, Bianchi DW. 2013a. Global gene expression analysis of term amniotic fluid cell-free fetal RNA. Obstet Gynecol 121: 1248-1254.

Hui L, Wick HC, Moise KJ Jr, Johnson A, Luks F, Haeri S, Johnson KL, Bianchi DW. 2013b. Global gene expression analysis of amniotic fluid cell-free RNA from recipient twins with twin-twin transfusion syndrome. Prenat $\mathrm{Di}$ agn 33: 873-883.

Hyland CA, Gardener GJ, O’Brien H, Millard G, Gibbons K, Tremellen A, Ochoa-Garay G, Flower RL, Hyett JA. 2014 Strategy for managing maternal variant RHD alleles in Rhesus D negative obstetric populations during fetal RHD genotyping. Prenatal Diagn 34: 56-62.
Koide K, Slonim DK, Johnson KL, Tantravahi U, Cowan JM, Bianchi DW. 2011. Transcriptomic analysis of cell-free fetal RNA suggests a specific molecular phenotype in trisomy 18. Hum Genet 129: 295-305.

Lamb J, Crawford ED, Modell JW, Blat IC, Wrobel MJ, Lerner J, Brunet J-P, Subramanian A, Ross KN. 2006. The connectivity map: Using gene-expression signatures to connect small molecules, genes, and disease. Science 313: 1929-1935.

Larrabee PB, Johnson KL, Lai C, Ordovas J, Cowan JM, Tantravahi U, Bianchi DW. 2005. Global gene expression analysis of the living human fetus using cell-free messenger RNA in amniotic fluid. JAMA 293: 836-842.

Lejeune J, Gautier M, Turpin R. 1959. Study of somatic chromosomes from 9 mongoloid children. C R Hebd Seances Acad Sci 248: 1721-1722.

Lewis C, Hill M, Skirton H, Chitty LS. 2012. Fetal sex determination using cell-free fetal DNA: Service users' experiences of and preferences for service delivery. Prenat Diagn 32: 735-741.

Li Y, Pan J, Li JL, Lee JH, Tunkey C, Saraf K, Garbe JC, Whitley MZ, Jelinsky SA, Stampfer MR, et al. 2007. Transcriptional changes associated with breast cancer occur as normal human mammary epithelial cells overcome senescence barriers and become immortalized. Mol Cancer 6: 7 .

Massingham LJ, Johnson KL, Scholl TM, Slonim DK, Wick HC, Bianchi DW. 2014. Amniotic fluid RNA gene expression profiling provides insights into the phenotype of Turner syndrome. Hum Genet 133: 1075-1082.

Parker SE, Mai CT, Canfield MA, Rickard R, Wang Y, Meyer RE, Anderson P, Mason CA, Collins JS, Kirby RS, et al. 2010. Updated National Birth Prevalence estimates for selected birth defects in the United States. Birth Defects Res A Clin Mol Teratoli 88: 1008-1016.

Rasmussen SA, Wong LY, Yang Q, May KM, Friedman JM. 2003. Population-based analyses of mortality in trisomy 13 and 18. Pediatrics 111: 777-784.

Rava RP, Srinivasan A, Sehnert AJ, Bianchi DW. 2014. Circulating fetal cell-free fractions differ in autosomal aneuploidies and monosomy X. Clin Chem 60: 243-250.

Roberts D, Gates S, Kilby M, Neilson JP. 2008. Interventions for twin-twin transfusion syndrome: A Cochrane review. Ultrasound Obstet Gynecol 31: 701-711.

Sambuy Y, De Angelis I, Ranaldi G, Scarino ML, Stammati A, Zucco F. 2005. The Caco-2 cell line as a model of the intestinal barrier: Influence of cell and culture-related factors on Caco-2 cell functional characteristics. Cell Biol Toxicol 21: 1-26.

Saunders NJ, Snijders RJ, Nicolaides KH. 1992. Therapeutic amniocentesis in twin-twin transfusion syndrome appearing in the second trimester of pregnancy. Am J Obstet Gyncol 166: 820-824.

Senat MV, Deprest J, Boulvain M, Paupe A, Winer N, Ville Y. 2004. Endoscopic laser surgery versus serial amnioreduction for severe twin-to-twin transfusion syndrome. N Engl J Med 351: 136-144.

Shah DM and Chaffin D. 1989. Perinatal outcome in very preterm births with twin-twin transfusion syndrome. Am J Obstet Gynecol 161: 1111-1113. 
Slonim DK, Koide K, Johnson KL, Tantravahi U, Cowan JM, Jarrah Z, Bianchi DW. 2009. Functional genomic analysis of amniotic fluid cell-free mRNA suggests that oxidative stress is significant in Down syndrome fetuses. Proc Nat Acad Sci 106: 9425-9429.

Song Y, Liu C, Qi H, Zhang Y, Bian X, Liu J. 2013. Noninvasive prenatal testing of fetal aneuploidies by massively parallel sequencing in a prospective Chinese population. Prenat Diagn 33: 700-706.

Subramanian A, Tamayo P, Mootha VK, Mukherjee S, Ebert BL, Gillette MA, Paulovich A, Pomeroy SL, Golub TR, Lander ES, et al. 2005. Gene set enrichment analysis: A knowledge-based approach for interpreting genome-wide expression profiles. PNAS 102: 15545 15550.

Tice RR, Agurell E, Anderson D, Burlinson B, Hartmann A, Koayashi H, Miyamae Y, Rojas E, Ryu JC, Sasaki YF. 2000. Single cell gel/comet assay: Guidelines for in vitro and in
Amniotic Fluid Transcriptome and Fetal Disease

vivo genetic toxicity testing. Environ Mol Mutagen 35: 206-221.

Visscher M, Narendran V. 2014. The ontogeny of skin. Adv Wound Care (New Rochelle) 3: 291-303.

Wick HC, Drabkin H, Ngu H, Sackman M, Fournier C, Haggett J, Blake JA, Bianchi DW, Slonim DK. 2014. DFLAT: Functional annotation for human development. BMC Bioinformatics 15: 45.

Wu C, Orozco C, Boyer J, Leglise M, Goodale J, Batalov S, Hodge CL, Haase J, Janes J, Huss JW, et al. 2009. BioGPS: An extensible and customizable portal for querying and organizing gene annotation resources. Genome Biol 10: R130.

Zwemer LM, Hui L, Wick HC, Bianchi DW. 2014. RNA-Seq and expression microarray highlight different aspects of the fetal amniotic fluid transcriptome. Prenat Diagn 34: 1006-1014. 


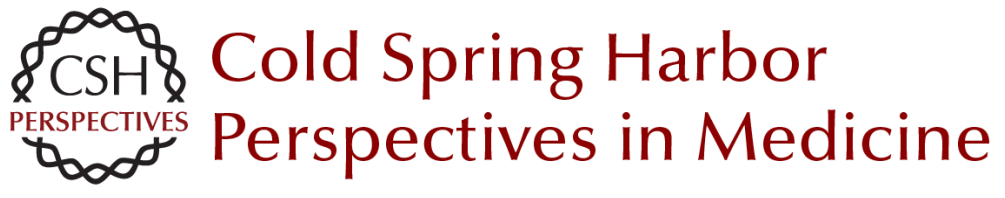

\title{
The Amniotic Fluid Transcriptome as a Guide to Understanding Fetal Disease
}

\author{
Lillian M. Zwemer and Diana W. Bianchi
}

Cold Spring Harb Perspect Med 2015; doi: 10.1101/cshperspect.a023101 originally published online February 13, 2015

Subject Collection Molecular Approaches to Reproductive and Newborn Medicine

\begin{abstract}
Intergenerational Transfer of Epigenetic
Information in Sperm

Oliver J. Rando

\section{Effects of Maternal Obesity on Fetal Programming: Molecular Approaches Caterina Neri and Andrea G. Edlow}

The Neonatal Salivary Transcriptome Jill L. Maron

The Role of Hox Genes in Female Reproductive Tract Development, Adult Function, and Fertility Hongling Du and Hugh S. Taylor

\section{Molecular Cross-Talk at the Feto-Maternal Interface}

Gendie E. Lash

\section{Molecular Regulation of Parturition: A Myometrial Perspective \\ Nora E. Renthal, Koriand'r C. Williams, Alina P. Montalbano, et al.}

Genome-Wide Sequencing for Prenatal Detection of Fetal Single-Gene Disorders

Ignatia B. Van den Veyver and Christine M. Eng

MicroRNA in Ovarian Biology and Disease

Lynda K. McGinnis, Lacey J. Luense and Lane K. Christenson
A Molecular Perspective on Procedures and Outcomes with Assisted Reproductive Technologies Monica A. Mainigi, Carmen Sapienza, Samantha Butts, et al.

Whole-Exome Sequencing and Whole-Genome Sequencing in Critically III Neonates Suspected to Have Single-Gene Disorders

Laurie D. Smith, Laurel K. Willig and Stephen F. Kingsmore

Noninvasive Antenatal Determination of Fetal

Blood Group Using Next-Generation Sequencing Klaus Rieneck, Frederik Banch Clausen and Morten Hanefeld Dziegiel

Potential Uses and Inherent Challenges of Using Genome-Scale Sequencing to Augment Current Newborn Screening Jonathan S. Berg and Cynthia M. Powell

Molecular Regulation of Parturition: The Role of the Decidual Clock Errol R. Norwitz, Elizabeth A. Bonney, Victoria V. Snegovskikh, et al.

Molecular Mechanisms of Preeclampsia Tammy Hod, Ana Sofia Cerdeira and S. Ananth Karumanchi

Noninvasive Prenatal Screening for Genetic Diseases Using Massively Parallel Sequencing of Maternal Plasma DNA Lyn S. Chitty and Y. M. Dennis Lo

Confrontation, Consolidation, and Recognition: The Oocyte's Perspective on the Incoming Sperm David Miller

For additional articles in this collection, see http://perspectivesinmedicine.cshlp.org/cgi/collection/ 